TAHKIM, Jurnal Peradaban dan Hukum Islam. Vol.2 No.l (Maret, 2019) | ISSN : 2597-7962

\title{
POSISI DAN METODE IJTIHAD YUSUF AL-QARADAWI TENTANG FISABILILLAH SEBAGAI ASNAF MUSTAHIQ ZAKAT DALAM PERBANDINGAN EMPAT MAZHAB
}

\author{
Ahmad Gunawan \\ Sekolah Pasca Sarjana UIN Syarif Hidayatullah Jakarta \\ Gugun_ahmad@yahoo.com
}

\begin{abstract}
ABSTRAK
Penelitian ini dilakukan untuk mempelajari dan memahami posisi dan metode ijtihad Yusuf al-Qaradawi dalam menyelesaikan permasalahan fiqih kontemporer untuk mengistinbatkan hukum Islam, khususnya ijtihad beliau tentang penyaluran zakat terhadap mustahiq zakat dalam relevansi masa kini. Penulis menemukan bahwa Yusuf al-Qaradawi telah mengunakan metode ijtihad lafdziyyah ( kaidah-kaidah kebahasaan) yang langsung pada nash (teks) dan melalui metode Maqasid al-Syariah berupa qiyas dan istislah dalam ijtihadnya tentang memaknai fisabilillah dalam mustahiq zakat.
\end{abstract}

Kata Kunci : Metode, ijtihad, Fisabilillah, Mustahiq zakat

\begin{abstract}
This study is aimed at observing and understanding Yusuf al-Qaradawi's position and method in ijtihad (independent reasoning in finding a solution to a legal question) pertaining to contemporary figh (Islamic law) issues, i.e. in doing istinbat (deducing) towards Islamic laws, particularly his ijtihad in distributing zakat (alms) to the mustahiq (recipients) related to the recent conditions. The study found that he used ijtihad lafdziyyah (language principle) directly to the nash (text) and Maqasid al-Syariah (the objective of shari'ah) method of qiyas (reasoning by analogy) and istisla $>h$ (reasoning by public interest) in his ijtihad pertaining to the understanding towards fisabilillah (those who fight in Allah's way) in terms of the mustahiq of zakat.
\end{abstract}

Keywords : Method, Ijtihad, fisabilillah, mustahiq of zakat.

\section{A. PENDAHULUAN}

Agama Islam adalah agama yang universal, ajarannya menyeluruh meliputi semua aspek kehidupan manusia yang berlaku disetiap tempat dan masa. Kendatipun agama Islam telah diturunkan berabad-abad lamanya namun hal ini tidak membuat ajaran Islam kaku dalam menghadapi perkembangan zaman yang semakin modern, ajaran Islam akan selalu eksis dalam setiap waktu dan zaman yang tidak akan usang ataupun lapuk dimakan usia. 
Salah satu kelebihan ajaran Islam yang senantiasa diterima bagi umatnya dalam mengarungi kehidupan ini adalah mempunyai intensitas sumber hukum Islam yang tetap yaitu bersumberkan al-Quran, as-Sunah dan $R a^{\prime} y u$ atau yang disebut oleh para ahlli usul fiqih adalah dalil naqly dan aqly. Dengan sumber pedoman inilah para mukallaf mengetahui bagaimana menjalani ajaran Islam sebagai rambu-rambu ataupun petunjuk pegangan hidupnya.

Secara luas ijtihad dapat dimaknai adalah mengerahkan segala potensi yang ada padanya guna memecahkan masalah-masalah baru dengan mengembalikannya kepada prinsip-prinsip yang ada dalam al-Quran dan al-Sunnah. ${ }^{1}$ Mengarahkan segala kemampuan dan usaha untuk mencapai sesuatu yang diharapkan. ${ }^{2}$ Ada unsur kesungguhan dan daya upaya sekuat tenaga yang dilakukan oleh seorang mujtahid untuk merumuskan ketetapan status hukum dari perkara yang sedang dihadapinya yang tidak terdapat kepastian hukumnya secara eksplisit dan tegas baik dalam alQuran maupun dalam al-Hadis.

Peranan ijtihad menurut Ibrahim Hosen pada garis besarnya dapat dibagi menjadi tiga segi, yaitu : pertama, ijtihad dilakukan untuk mengeluarkan hukumdari dhahir nash manakala persoalan itu dapat dimasukan kedalam lingkungan nash. Cara ini dilakukan setelah memeriksa tentang keadaan nash itu, 'amm-kah ia atau khas, mutlaq-kah atau muqayyad, nasikh-kah atau mansu>kh, dan hal-hal lain lagi yang bersangkutan dengan lafaz (kata). Kedua, ijtihad dilakukan untuk mengeluarkan hukum yang tersirat dari jiwa dan semangat nash dengan memeriksa lebih dahulu apakah yang menjadi 'illat bagi hukum nash itu: 'illat mansusah ataukah mustanbatah, 'illat qasirah ataukah muta'addiyah, dan sebagainya. Cara ini dikenal dengan Qiyas.Ketiga, ijtihad dilaksanakan untuk mengeluarkan hukum dari kaidahkaidah umum yang diambil dari dalil-dalil yang tersebar dan terdapat didalam alQuran ataupun al-Hadist. Cara ini terkenal dengan istishab, masalih mursalah, sadd al-Dzar'i, istihsan dan lain sebagainya. Dari ketiga segi ini teranglah bahwa ijtihad tidak akan dipergunakan manakala terdapat nash yang sharih. ${ }^{3}$

${ }^{1}$ Muhammad Ali al-Sayis, Nasy'ah al-Fiqh al-Ijtihadi wa Athwaruh,(Cairo: Majma' alBuhuts al-Islamiyyah, 1970), hlm. 30.

2 A. Djazuli, Ilmu Fiqh, Perkembangan dan Penerapan Hukum Islam, (Jakarta: Kencana, 2005), hlm. 71. hlm. 15-16.

${ }^{3}$ Ibrahim Hosen, Fiqh Perbandingan, Masalah Pernikahan, (Jakarta: Pustaka Firdaus, 2003), 
Yusuf al-Qaradawi menolak pendapat yang menganggap bahwa para ulama terdahulu sudah cukup dalam menjawab permasalahan-permasalahan fikih. Baginya, perputaran zaman dan kebutuhan manusia yang terus berkembang mau tidak mau juga membutuhkan jawaban-jawaban baru yang tidak sedikit. Hal inilah yang melahirkan pernyataan "perubahan fatwa disebabkan perubahan waktu, tempat, adat kebiasaan, dan kondisi konkritnya ${ }^{4} "$. Al-Qaradawi dalam buku-bukunya selalu menekankan urgensi ijtihad sebagai upaya untuk menghadapi tantangan syari'at Islam pada zaman sekarang. Bahkan melalui teori ijtihadnya, ia mencoba memecahkan persoalan hukum yang berkembang pada masa kontemporer. ${ }^{5}$ Ia tidak bertaqlid buta untuk mengekor kepada para pemikir sebelumnya atau berhenti dalam pendapat seseorang akan tetapi ia berusaha mentarjih atau menyeleksi para pendapat ahli fiqih lalu kemudian ia mentashih nya (memperbaiki) sehingga dari ijihadnya itu mempunyai relevansi yang sesuai dengan kehidupan sekarang dan memprioritaskan kemaslahatan bagi manusia.

Salah satu tema yang diangkat oleh penulis adalah ijtihad pendapat Yusuf alQaradawi yang mencoba memberi gagasan baru tidak bersependapat dengan jumhur ulama dari empat mazhab besar, yaitu mazhab Al-Hanafiyah, Al-Malikiyah, AsySyafi'iyah dan Al-Hanabilah mereka berpendapat bahwa yang termasuk fisabilillah adalah perang Islam dan jihad dalam mempergunakan bala tentara, seperti perangnya para sahabat dan tabi'in yang berjuang dengan nama Allah. ${ }^{6}$ Sementara Yusuf alQaradawi berpendapat bahwa arti kalimat sabi>lillah menurut bahasa aslinya sudah jelas yang bermakna thariq (jalan), yaitu jalan yang menyampaikan pada ridha Allah, baik akidah maupun perbuatan. ${ }^{7}$ Perbedaan pendapat Yusuf al-Qaradawi terhadap empat mazhab imam besar inilah yang kemudian menjadi salah satu melatar belakangi penelitian ini.

\footnotetext{
${ }^{4}$ Yusuf al-Qaradawi mengutip dari al-Mu'tamar al-Awwal yang dikeluarkan oleh Majma' alBuhūts. Dalam buku beliau Min Ajl Shahwah Rasyīdah; Tujaddid al-Dīn wa Tanhadh bi al-Dunyā, (Kairo: Dar al-Syuruq, 2001), hlm. 101.

${ }^{5}$ Siti Aminah, "Pengaruh Pemikiran Fiqh Yusuf al-Qardhawi Di Indonesia", Jurnal Ummul Qura, Vol. V, No. 1, (Maret 2015), hlm. 61.

${ }^{6}$ Yusuf al-Qaradawi, Fiqhu az-Zakah, (Kairo: Maktabah Wahbah, jilid 2, 1994), hlm. 705.

${ }^{7}$ Ibid. hlm. 679.
} 
TAHKIM, Jurnal Peradaban dan Hukum Islam. Vol.2 No.l (Maret, 2019) | ISSN : 2597-7962

\section{B. METODE PENELITIAN}

Metode yang digunakan dalam penelitian ini adalah metode kualitatif normatif yaitu telaah untuk memecahkan suatu masalah yang pada dasarnya bertumpu pada penelaahan kritis dan mendalam terhadap bahan-bahan pustaka yang relevan. Dengan kata lain metode penelitian kualitatif adalah penelitian yang mengungkap situasi sosial tertentu dengan mendeskripsikan kenyataan secara benar, dibentuk oleh katakata berdasarkan data yang relevan yang diperoleh dari situasi yang alamiah. ${ }^{8}$

\section{PEMBAHASAN}

\section{Pengertian Fisabilillah}

Salah satu mustahiq zakat yang disebutkan dalam surat at-Taubah ayat 60 adalah fisabilillah. Secara bahasa fisabilillah berasal dari bahasa Arab, terdiri dari tiga kata; fi, sabil dan Allah ( في, سبيل, الله ), kata fi sendiri mengandung arti dalam, di, pada, didalam, selama, diantara, beserta. ${ }^{9}$ abil memiliki makna jalan, jalur, sarana, medium, alat, cara, ${ }^{10}$ dan lafad Allah adalah Allah subhana wa ta'la. Jadi kalau dirangkaikan secara harfiah kalimat fisabilillah memiliki makna di jalan Allah.

Makna fisabilillah menurut pendapat ulama mazhab empat imam mazhab :

a. Pendapat ulama mazhab imam Abu Hanifah : "Fisabilillah adalah para tentara yang disiapkan oleh pemimpin mereka untuk berperang bertujuan menegakan agama Allah. Maka tidak diperbolehkan menyalurkan harta zakat yang sudah terkumpul untuk membangun masjid atau untuk keperluan pengurusan jenazah, karena harta zakat bukanlah harta untuk keperluan kemaslahatan umum melainkan harta zakat diperuntukan bagi para mustahiq yang sudah ditetapkan oleh syar'i'. ${ }^{11}$

b. Pendapat ulama mazhab imam Malik : "Fisabilillah adalah orang yang berjihad (berperang) tidak termasuk orang yang sedang berhaji. Sasaran harta

${ }^{8}$ Djam`an Satori, Aan Komariah, Metodologi Penelitian Kualitatif,(Bandung. Alfabeta, 2009), hlm. 25.

${ }^{9}$ Atabik Ali, Ahmad Zuhdi Muhdlor, Kamus Kontemporer Arab-Indonesia, (Yogyakarta: Multi Karya Grafika,1999), hlm. 1412-1413.

${ }^{10} \mathrm{Al}-\mathrm{Maany}$, Terjemahan dan Arti Fisabilillah di Kamus Istilah Umum Indonesia Arab, dalam https://www.almaany.com/ diakses pada jumat, 25 Mei 2018, pukul 15:00 WIB).

${ }^{11}$ Muhidin Abdul Hamid, Sabilulfalah fi Syarhi Nurulidhoh lilsyarnabulani,(Damsuq: Darul al-Biruti, 1990), hlm. 226. 
TAHKIM, Jurnal Peradaban dan Hukum Islam. Vol.2 No.l (Maret, 2019) | ISSN : 2597-7962

zakat bagi fisabilillah digunakan untuk kebutuhan berjihad seperti membeli persenjataan, kuda, pertahanan perang dan sejenisnya". ${ }^{12}$ Imam al-Qurtubi ahli tafsir yang menganut aliran mazhab Maliki mengatakan : "Fisabilillah adalah pejuang yang memiliki ikatan; harta zakat diberikan kepada mereka sebagai kebutuhan mereka dalam peperangan baik kaya atau miskin". ${ }^{13}$

c. Pendapat ulama mazhab imam Syafi'i : “ Bagian untuk fisabilillah adalah mereka para pejuang peperangan yang aktif berperang langsung, namun apabila mereka diupah dari kas negara sebagai bagian dari tentara muslim (PNS) maka mereka tidak mendapatkan bagian dari hartza zakat tersebut, karena pada hakekatnya mereka telah mengambil rezeki dan upah mereka dari bagian harta fai', diberikan kepada orang yang kaya ataupun miskin, dan apabila ia mengambil bagian harta zakat dan tidak ikut berperang maka harta zakat tersebut mesti dikembalikannya". ${ }^{14}$

d. Pendapat ulama mazhab imam Hanbali :" Fisabilillah adalah mereka para pejuang peperangan yang aktif berperang langsung yang tidak dinafkahi oleh negara (sukarela), mereka diberi bagian zakat sekedar mencukupi untuk kebutuhan perang; seperti keperluan untuk perjalanan dan akomodasi perjuangan mereka, membeli senjata perang dan kuda jika mereka pasukan berkuda walaupun mereka termasuk orang yang kaya serta tidak diberikan kepada orang-orang yang bekerja untuk mengurus kuda dan bawaan mereka, karena mereka (pejuang perang) telah memberikan kemaslahatan bagi kaum Muslimin". ${ }^{15}$

Keempat mazhab tersebut telah mengungkapkan definisi fisabilillah yang cenderung menyempitkan maknanya, lebih mengkhususkan makna fisabilillah dengan jihad; peperangan, pertempuran dimedan perang dan segala sesuatu yang berkaitan dengannya. Hal ini menyebabkan harta zakat tersebut hanya dapat dipergunakan dan diberikan untuk kepentingan peperangan.

\footnotetext{
12 Abu Muhammad Abdulwahab al-Bagdadi ,At-Talqin fi al-Fiqhi al-Maliki, (ArRiyad:Nazar Mustofa,2003), hlm. 171.

13 Abu Abdullah Muhammad bin Ahmad al-Anshari al-Qurtubi, al-Jami li Ahkam alQuran (Kairo : Dar al- Kitab al-Arabi , 1962), hlm. 180.

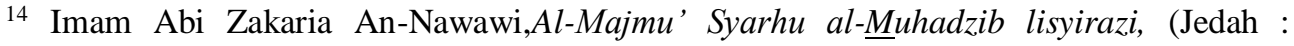
Maktabah al-Irsyad,1990), hlm. 192.

${ }^{15}$ Ahmad Ibnu Muhamad Ibnu Qudamah al-Hanbali, Al-Kafi, (Kairo : Hajar, 1997), hlm. 201.
} 
TAHKIM, Jurnal Peradaban dan Hukum Islam. Vol.2 No.l (Maret, 2019) | ISSN : 2597-7962

Adapun para ulama yang cenderung memaknai fisabilillah secara luas ataupun umum dengan meliputi segala aspek kebaikan dan ketaatan yang bertujuan menciptakan kemaslahatan umat dan kepentingan agama Islam demi meraih ridha Allah maka itulah fisabilillah yang sebenarnya, ulama golongan yang meluaskan makna fisabilillah tersebut diantaranya adalah :

a. Imam Muhamad ar-Razi seorang ahli tafsir dan fiqih mengatakan dalam kitab tafsirnya; Tafsiru al-Fakhri ar-Razi : “ Ketahuilah bahwa zahir lafad dalam firman-Nya "fisabilillah" tidak harus mengkhususkan artinya pada orang yang berperang saja. Kemudian ia berkata : " bahwa makna fisabilillah; Imam Qaffal menukil dalam tafsirnya dari sebagian fuqaha, bahwa mereka membenarkan untuk menggunakan zakat, pada semua bentuk kebaikan, seperti untuk pengurusan jenazah, mendirikan bangunan, meramaikan mesjid. Karenanya sesunguhnya firman-Nya "fisabilillah" bersifat umum yang mencakup semuanya". ${ }^{16}$

b. Syaikh Muhamad Abu Zahra salah satu ulama al-Azhar mengutip makna fisabilillah dalam tafsirnya ialah : "Imam al-Qaffal as-Syasi menentukan bagian zakat $f i$ sabilillah adalah termasuk meliputi semua model kebaikan". ${ }^{17}$

c. Syaikh Muhamad Abduh seorang pionir Mesir dan Muhamad Rasyid Ridha dalam kitab tafsir al-Manar mengungkapkan bahwa realisasi dari makna fi sabilillah adalah untuk kemaslahatan kaum muslimin secara umum dalam menegakan urusan (kepentingan) agama dan negara dan bukan untuk urusan pribadi. Ibadah haji termasuk kepentingan pribadi dan tidak termasuk kemaslahatan umum; karena ibadah haji hanya wajib bagi orang yang mampu untuk melaksanakannya dan tidak diwajibkan bagi orang yang tidak mampu, maka ibadah haji termasuk kedalam fardhu 'ain yang memiliki syarat-syarat tertentu seperti halnya ibadah shalat dan puasa yang bukan kategori kemaslahatan agama ataupun negara yang bersifat umum, akan tetapi apabila diperlukan untuk kepentingan syiar

\footnotetext{
${ }^{16}$ Imam Muhamad ar-Razi Fakhrudin, Tafsiru al-Fakhri ar-Razi, (Baerut : Darul-al-Fikri 1981), hlm. 116. 3348.

${ }^{17}$ Muhamad Abu Zahra, Zahratu at-Tafasir,( Kairo : Darul al-Fikri al-Arabi 1995), hlm.
} 
TAHKIM, Jurnal Peradaban dan Hukum Islam. Vol.2 No.l (Maret, 2019) | ISSN : 2597-7962

ibadah haji demi kemaslahatan umat maka dibolehkan untuk mengunakan bagian zakat tersebut dalam pelaksanaannya, seperti untuk kenyamanan dan keamanan jalan-jalan yang akan dilalui para jemaah haji, memenuhi kebutuhan air dan makanan serta pemeliharaan kesehatan bagi para jemaah, hal tersebut diperbolehkan apabila tidak ada mustahiq zakat yang lain". ${ }^{18}$

d. Sayid Sabiq salah satu fuqaha kontemporer asal Mesir mengatakan dalam kitab fikih as-Sunnah : “Fisabilillah adalah usaha yang mengantarkan kepada keridhan-Nya, baik berupa ilmu ataupun amal". ${ }^{19}$

e. Teungku Muhamad Hasbi Ash Shiddiqy salah satu mufasir Indonesia kelahiran tanah Rencong Lhokseumawe Aceh yang juga seorang Propesor dalam bidang ilmu syariat Islam di IAIN Sunan Kalijaga, berpendapat mengenai makna fisabilillah dalam kitab tafsirnya "Tafsir Al-Qur'anul Majid An-Nur" : wa fisabilillahi adalah dan untuk di jalan Allah. Termasuk ke dalamnya biaya untuk para pejuang dan para pengawal perbatasan. Juga masuk kedalamnya segala pekerjaan kebajikan seperti mengkafankan orang mati, membangun jembatan, benteng dan mesjid dan lain-lain yang seperti itu, asrama sekolah, rumah-rumah penyantun dan lain-lain. Ada yang berpendapat, bahwa yang dikehendaki dengan fisabilillah ini hanyalah belanja para pejuang saja. Sebenarnya yang dikehendaki dengan fisabilillah ialah segala kemaslahatan umat dan segala rupa kebajikan untuk meningkatkan kesejahteraan. Dan masuk ke dalamnya usaha-usaha memudahkan perjalanan haji". ${ }^{20}$

f. Bachtiar Surin ulama asal Sumatera Barat yang menulis tafsir al-Qur'an 30 juz lengkap Arab dan latinya, berpendapat bahwa makna fisabilillah dalam ayat 60 surat at-Taubah adalah : "Maksudnya, usaha untuk mencapai kerelaan Allah, misalnya : peperangan, membantu jema'ah haji

${ }^{18}$ Muhamad Abduh dan Muhamad Rasyid Ridha, Tafsir al-Manar, (Kairo : Darul-al-Manar 1990), hlm. 585.

${ }^{19}$ Sayyid Sabiq, Fiqhu as-Sunnah, (Kairo: al-Fathu lili'lami al-A'rabi, 2006), hlm. 280.

${ }^{20}$ Teungku Muhamad Hasbi Ash Shiddiqy, Tafsir Al-Qur'anul Majid An-Nur,(Semarang : PT Pustaka Rizki Putra Semarang 1995), hlm. 1628. 
yang kehabisan bekal, pelajar dan mahasiswa yang putus biaya dan lainlain". ${ }^{21}$

g. Zaini Dahlan yang memprakarsai penulisan kitab “Al-Qur'an dan Tafsirnya" terbitan PT. Dana Bhakti Wakaf (milik badan wakaf Universitas Islam Indonesia), juga mantan rektor di Universitas tersebut dan mantan rektor IAIN Sunan Kalijaga, berpendapat mengenai fisabilillah : "Perkataan sabilillah mempunyai dua arti. Pertama arti khusus, yaitu orang-orang yang secara suka-rela menjadi tentara melakukan jihad membela agama Allah terhadap orang-orang kafir yang mengganggu keamanan kaum Muslimin. Kedua arti umum, yaitu segala perbuatan yang bersifat kemasyarakatan yang ditujukan untuk mendapatkan keridhaan Allah seperti : membuat jembatan, rumah sakit, rumah sekolah, langgar, untuk pembangunan atau pemeliharaan masjid dan madrasah demikian juga untuk kegiatan ulama dan para mubalig dapat diambil dari harta zakat. ${ }^{22}$

Makna fisabilillah lebih relevan di masa sekarang bagi umat Islam bila diartikan dengan makna umum; meliputi segala aspek kebaikan dan ketaatan yang bertujuan menciptakan kemaslahatan umat dan tidak hanya diartikan dengan arti khusus bagi orang yang berjihad; berperang langsung melawan musuh-musuh Allah.

Perdebatan dua kelompok ini,( Asbabul Ikhtilaf) disebabkan perbedaan para ulama dalam memaknai arti fisabilillah. Sebagian ulama berpendapat makna fisabillah mengandung arti khusus (معني خاص), mengkhususkan arti fisabilillah dengan arti jihad, berperang, bertempur melawan orang-orang kafir demi menegakkan kalimah Allah. Sementara sebagian ulama yang lainya menafsirkan arti fisabilillah memiliki arti umum (معني عام); meliputi semua aspek kebaikan, taqarub, ketaatan yang bertujuan untuk kemaslahatan umat dan kepentingan agama Islam dalam meraih ridha Allah maka itulah makna fisabilillah yang bersifat umum.

21 Bachtiar Surin, Adz-Dzikraa Terjemah \& Tafsir Al-Qur'an,(Bandung, Angkasa Bandung 1991), hlm.783.

${ }^{22}$ Universitas Islam Indonesia,Al-Qur'an dan Tafsirnya,( Yogyakarta : PT Dana Bhakti Wakaf 1995), hlm. 170. 


\section{Ijtihad al-Qaradawi dalam Pemaknaan Fisabilillah}

Al-Qaradawi cukup berani dalam mengeluarkan ijtihadnya tentang pemaknaan fisabilillah. Ia telah menggunakan model ijtihad kontemporer integrasi antara ijtihad intiqai (selektif) dan ijtihad insyai (imajinatif) dalam memaknai fisabilillah.

Ijtihad kontemporer integrasi antara ijtihad selektif dengan ijtihad imajinatif yaitu dengan cara menyeleksi pendapat-pendapat ulama terdahulu yang dipandang relevan dengan zaman sekarang dan lebih kuat, kemudian menambahkan dalam pendapat tersebut unsur-unsur ijtihad baru. ${ }^{23}$

Posisi ijtihad al-Qaradawi tidak menyempitkan makna fisabillah dengan arti jihad berperang dimedan perang juga tidak memaknainya dengan terlalu meluaskan arti dengan segala asfek kebaikan ketaatan kepada Allah, akan tetapi mengartikannya masih dalam koridor arti jihad dizaman sekarang ini, karena arti jihad bukan hanya sekedar berperang dimedan perang namun memiliki banyak arti. Salah satu argumentasinya adalah :

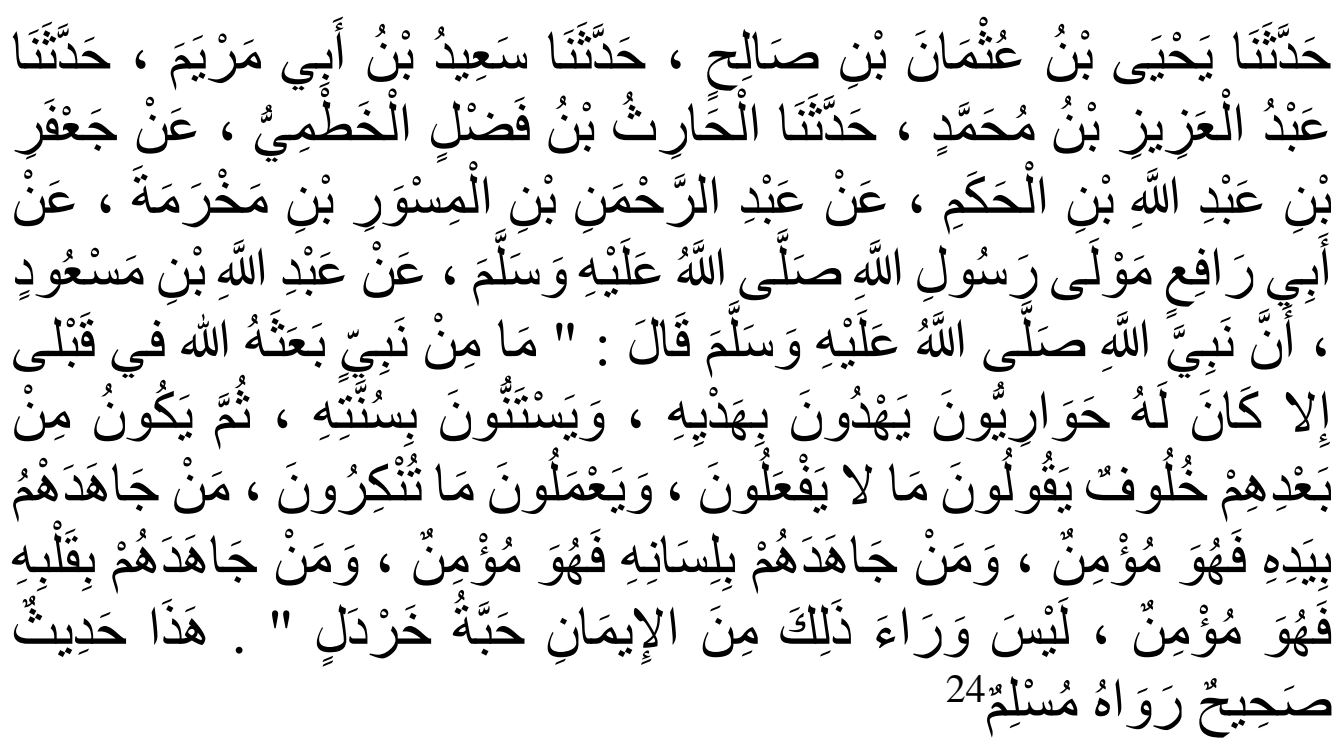

Telah bercerita kepada kami Yahya bin Ustman bin Shaleh, telah bercerita kepada kami Said bin Abi Maryam, telah bercerita kepada kami Abdulazis bin Muhamad, telah bercerita kepada kami al-Harist bin Fadlin al-Khathami, dari Ja'far bin Abdillah bin al-Hakam, dari Abdurahman bin al-Miswari bin Mukhramah, dari Abi Rafi seorang pelayan Rasulullah saw, dari Abdillah bin

\footnotetext{
${ }^{23}$ Yusuf al-Qarada>wi>, Ijtihad Dalam Syariat Islam Beberapa Pandangan Analitis tentang Ijtihad Kontemporer, terj : Achmad Syathori, (Jakarta: PT Bulan Bintang, 1987), hlm. 173.

${ }^{24}$ Abdullah Nashihu I'lwan, Ahkamu az-Zakat a 'la Dhawai al-Mazdahib al-Arba'ah,(Kairo: Darul as-Salam,2000),hlm. 38.
} 
TAHKIM, Jurnal Peradaban dan Hukum Islam. Vol.2 No.l (Maret, 2019) | ISSN : 2597-7962

Masu'din, Sesungguhnya Nabi Allah saw telah bersabda :"Tiada dari seorang Nabi pun sebelum aku yang diutus oleh Allah kepada suatu umat, kecuali pasti ada dari umat itu golongan orang yang membelanya, sahabat-sahabat yang mengikuti sunahnya dan mengikuti perintahnya, kemudian setelah itu datang pula para penggantinya, mereka mengatakan apa yang tidak dilakukanya, dan mengerjakan apa yang tidak diperintahkan. Barang siapa yang berjihad melawan mereka dengan tangannya, maka orang itu adalah orang yang beriman, barang siapa yang berjihad melawan mereka dengan lisannya, maka orang itu adalah orang yang beriman, dan barang siapa yang berjihad melawan mereka dengan hartanya, maka orang itu adalah orang yang beriman, dan barang siapa yang berjihad melawan mereka dengan hatinya, maka orang itu adalah orang yang beriman dan tiada setelah itu dari keimanan seseorang walaupun sebesar biji sawi" . (Hadist ini Shahih diriwayatkan oleh Imam Muslim).

Dasar pendapat ijtihad ini, dilihat dalam konteks fiqih realitas (Fiqh al-Waqi') bukan hanya sekedar berdasarkan tekstual saja namun memadukan antara tekstual dan kontekstual seperti zaman sekarang ini,dimana medan laga untuk berjihad langsung tentunya skalanya sedikit sekali bila dibandingkan dengan zaman Rasul dan para sahabat, sementara realiatas dilapangan sangat membutuhkan materi dalam menyukseskan dakwah, baik untuk kebutuhan pendakwahnya ataupun transfortasi, akomodasi dan prasarana yang dibutuhkan dilapangan untuk keperluan berdakwa, seperti kurangnya madrasah, masjid, sekolah-sekolah Islam padahal itu semua adalah penunjang keseuksesan dalam menyebarkan ajaran Islam.

Adapun ijtihad al-Qaradawi dalam permasalahan ini adalah “ Tepatlah tidak meluaskan maksud sabilillah untuk segala perbuatan yang menimbulkan kemaslahatan dan takarrub kepada Allah; sebagaimana tepatnya tidak terlalu menyempitkan arti kalimat ini hanya untuk jihad dalam arti bala tentara saja. Sesungguhnya jihad itu kadangkala bisa dilakukan dengan tulisan dan ucapan sebagimana bisa dilakukan pula dengan pedang dan pisau. Kadangkala jihad itu dilakukan dalam bidang pemikiran, pendidikan, sosial, ekonomi, politik sebagimana halnya dilakukan dengan kekuatan bala tentara. Seluruh jenis jihad ini membutuhkan bantuan dan dorongan materi. Yang paling penting, terwujudnya syarat utama pada semuanya itu, yaitu hendaknya sabilillah itu dimaksudkan untuk membela dan menegakan kalimat Islam di muka bumi ini. Setiap jihad yang dimaksudkan untuk menegakkan kalimat Allah, termasuk sabilillah, bagaimanapun keadaan dan bentuk 
jihad serta senjatanya". ${ }^{25}$ Interferensi al-Qaradawi dalam ijtihad ini, tidak menyempitkan makna fisabillah dengan arti jihad berperang dimedan perang juga tidak memaknainya dengan terlalu meluaskan arti dengan segala asfek kebaikan ketaatan kepada Allah, akan tetapi mengartikannya masih dalam koridor arti jihad dizaman sekarang ini, karena arti jihad bukan hanya sekedar berperang dimedan perang namun memiliki banyak arti.

Ijtihad al-Qaradawi dalam memaknai fisabilillah pada mustahiq zakat salah satunya telah menerapkan metode ijtihad lafdziyyah, berupa lafdż muqayyad yang dibatasi maknanya dengan arti orang yang berjihad. Dalam mengartikan fisabilillah, al-Qaradawi memahaminya secara tekstual, bahwa lafadz fisabilillah memiliki lafadz muqayyad; maknanya sudah terikat dengan makna yang sudah ditentukan, jelas dan pasti. Arti jihad itulah yang dimaksud fisabilillah dalam ayat zakat tersebut, sehingga tidak perlu meluaskan maknanya dengan beragam makna kebaikan atau ketaatan namun lebih membatasi maknanya dengan arti jihad.Kalaupun lafadz fisabilillah diartikan dengan makna umum karena mengandung lafdz mutlaq yang tidak bisa dibatasi maknanya atau dipersempit cangkupan batasan arti dari lafadz nash ayat fisabilillah maka akan mengaburkan makna dari tujuan ayat zakat tersebut. Kalaupun lafadz ayat zakat tesebut masuk kedalam lafadz ayat yang bersifat global maka akan dibatasi dari sejumlah obyek-obyek yang terkandung dalam lafadz al'am tersebut menjadi arti khusus yang memastikan menjadi satu obyek yang memiliki arti jihad. Dalam istilah ulama ushul hal ini disebut dengan takhshisu al- 'Am; membatasi atau mempersempit dari umun menjadi khusus karena ada dalil yang menunjukan demikian. ${ }^{26}$

Fisabilillah yang bermakna luas ataupun umum, mencakup semua kebaikan dan ketaatan yang bertujuan menciptakan kemaslahatan umat dapat dibatasi makna keumumannya dengan mengambil metode takhshisu al-'Am sehingga maknanya menjadi pasti tidak mengandung beragam makna yang bersifat umum, menjadi khusus bermakna jihad, dengan petunjuk dalil al-Hadist sebagai sarana atau alat yang digunakan untuk melakukan takhshisu al-'Am yang disebut dengan al-mukhashhis

\footnotetext{
${ }^{25}$ Yusuf al-Qaradawi, Fiqhu az- Zakah., hlm. 632.

${ }^{26}$ Romli SA, Muqaranah Mazahib fil Ushul,(Jakarta: Radar Jaya Pratama.1999), hlm. 198.
} 
sebagai dalil atau alasan yang dapat dijadikan pegangan dalam membatasi keumuman makna fisabilillah, diantaranya adalah :

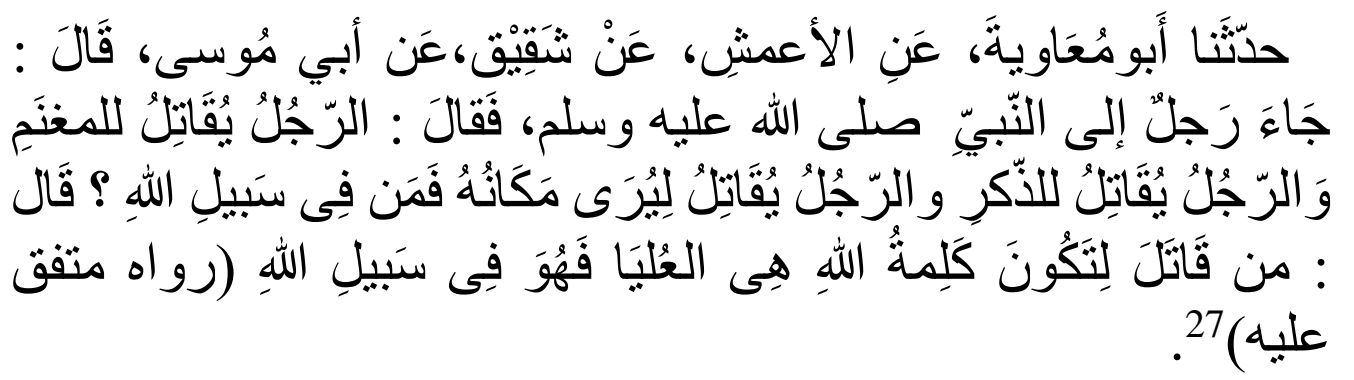

Telah becerita kepada kami Abu Mua'wiyyah, dari A'masy dari Syaqiq dari Abi Musa berkata: Seorang laki-laki menghadap kepada Nabi saw, lalu berkata : “Ada orang yang berperang karena hendak mendapat rampasan (harta), ada yang berperang karena ingin disebut orang(popuraritas), ada yang berperang karean ingin dilihat orang (pencitraan), lantas manakah yang termasuk fisabilillah? Beliau bersabda : "Siapa yang berperang untuk menegakan kalimah (agama) Allah menjadi tinggi, maka itulah yang disebut "fisabilillah" berperang dijalan Allah."(HR.Muttafaqunalaih).

Dalil hadist tersebut merupakan bayan takhsis atau disebut jua dengan mukhashhis sebagai petunjuk atau alasan yang dapat dijadikan pegangan dalam membatasi keumuman, membatasi makna fisabilillah yang memiliki banyak arti menjadi pasti, bermakna khusus bahwa fisabilillah itu mereka yang berjihad dijalan Allah.

Kemudian al-Qaradawi melanjutkan pendaptanya : "Bahwa makna umum dari sabilillah itu tidak layak dimaksudkan dalam ayat ini, karena dengan keumumanya ini akan meluas pada aspek-aspek yang banyak sekali, tidak terbatas sasaranya dan apalagi terhadap orang-orangnya. Makna umum ini meniadakan pengkhususan sasaran zakat yang delapan, sebagaimana yang ditetapkan dalam ayat zakat tersebut". ${ }^{28}$ Walaupun demikian al-Qaradawi berpendapat maksud jihad dari makna fi sabilillah dalam ayat zakat tersebut bukan hanya arti jihad yang berperang dimedan perang saja, namun lebih meluaskan arti jihad dengan beragam objek yang

\footnotetext{
${ }^{27}$ Imam Abi al-Husain Muslim, $\underline{S} h a h i>h$ Muslim,(Berut : Dar al-Kutub al-'Ilmiyyah,2003), hlm. 759.

${ }^{28}$ Yusuf al-Qaradawi, Fiqhu az- Zakah., hlm. 631.
} 
digelutinya, lebih mengedepankan kontektual dan realitas jihad yang ada dizaman sekarang ini. Al-Qaradawi mengartikan fisabilillah dengan jihad, sebagaimana yang diartikan para ulama tafsir umumnya. Akan tetapi jihad yang dimaksudnya adalah jihad dalam bentuk tulisan, lisan, pemikiran, pendidikan, sosial, budaya serta politik yang kesemuanya itu digunakan untuk keagungan dan kepentingan agama Islam, namun Elaborasi makna jihad ini tidak keluar dari makna spirit jihad dan tetap mengacu pada tujuan syariah dalam memperjuangkan agama Islam dan menegakan kalimah Allah, sehingga ijtihad model ini bisa mengambil jalan tengah diantara yang mempersempit dan memperluas makna fisabilillah.

Bukan tanpa alasan Yusuf al-Qaradawi mengelaborasi makna jihad dengan meluaskan maknanya,banyak hadist dengan riwayat yang shaheh menerangkan makna jihad bukan hanya sekedar para mujahid yang bertempur dimedan laga. Para mujahid yang mengimplikasikannya tidak hanya terbatas dengan berperang atau berjuang melawan musuh secara fisik namun lebih jauh lagi adalah berdakwah dan berjuang melalui lisan, tulisan dan berbagai kegiatan lainnya yang dapat membangkitan kekuatan Islam dimuka bumi ini. Salah satu argumentasinya berdasarkan petunjuk hadist, berikut ini : "Telah bercerita kepada kami al-Ha>rist bin Fadlin al-Khathami, dari Ja'far bin Abdillah bin al-Hakam, dari Abdurahman bin alMiswari bin Mukhramah, dari Abi Rafi seorang pelayan Rasulullah saw, dari Abdillah bin Masu'din, Sesungguhnya Nabi Allah saw telah bersabda :"Tiada dari seorang Nabi pun sebelum aku yang diutus oleh Allah kepada suatu umat, kecuali pasti ada dari umat itu golongan orang yang membelanya, sahabat-sahabat yang mengikuti sunahnya dan mengikuti perintahnya, kemudian setelah itu datang pula para penggantinya, mereka mengatakan apa yang tidak dilakukanya, dan mengerjakan apa yang tidak diperintahkan. Barang siapa yang berjihad melawan mereka dengan tangannya, maka orang itu adalah orang yang beriman, barang siapa yang berjihad melawan mereka dengan lisannya, maka orang itu adalah orang yang beriman, dan barang siapa yang berjihad melawan mereka dengan hartanya, maka orang itu adalah orang yang beriman, dan barang siapa yang berjihad melawan mereka dengan hatinya, maka orang itu adalah orang yang beriman dan tiada 
TAHKIM, Jurnal Peradaban dan Hukum Islam. Vol.2 No.l (Maret, 2019) | ISSN : 2597-7962

setelah itu dari keimanan seseorang walaupun sebesar biji sawi”. (Hadist ini Shahih diriwayatkan oleh Imam Muslim) ${ }^{29}$.

Dasar pendapat dalam ijtihad tersebut, tentunya atas petunjuk dalil hadis diatas, menjelaskan makna jihad bukan hanya sekedar berjuang mengangkat senjata, berperang secara fisik melawan musuh Allah di medan perang namun jihad beragam cara dan objeknya, bisa berjihad dengan mengorbanka harta benda yang ia miliki, Allah swt berfirman : "Dan berjihadlah dengan harta dan dirimu dijalan Allah “.(QS. At-Taubah[9];41). ${ }^{30}$ Ataupun dengan lisan yang ia ucapkan, menasehati dan mengungkap kebenaran serta memperjuangkan keadilan terhadap penguasa yang tirani adalah termasuk jihad dengan lisan, Rasulullah saw bersabda :"Jihad yang paling utama adalah mengatakan kebenaran di hadapan penguasa yang zalim”. (HR. Abu Daud, Tirmidzi dan Ibnu Majah). ${ }^{31}$ Termasuk tablig; menyampaikan petunjuk untuk menjawab tuduhan sesat yang diarahkan kepada Islam, ataupun da'wah, menegakkan amar ma'ruf nahi munkar, Allah swt berfirman : "Mereka menyuruh (mengerjakan)yang ma'ruf, mencegah dari yang mungkar, mendirikan sembahyang,menunaikan zakat, dan mereka ta'at kepada Allah dan Rasul-Nya. Mereka itu akan diberi rahmat oleh Allah; sesungguhnya Allah Maha Perkasa lagi Maha bijaksana”. (QS. At-Taubah[9];71). ${ }^{32}$ Bentuk jihad yang lain adalah ta'lim; mengajarkan ilmu kepada orang lain sehingga bermanfaat bagi dirinya dunia dan akhirat. Allah swt berfirman : “Tidak sepatutnya bagi orang mu'min itu pergi semuanya (kemedan perang). Mengapa tidak pergi dari tiap-tiap golongan diantara mereka beberapa orang untuk memperdalam pengetahuan mereka tentang agama dan untuk memberi peringatan kepada kaumnya apabila mereka telah kembali kepadanya, supaya mereka itu dapat menjaga dirinya”. (QS. At-Taubah[9];122). ${ }^{33}$

Dilihat dari tujuan makna jihad inilah, al-Qaradawi kemudian mengqiyaskan dengan orang-orang yang sibuk berda'wah, mencari ilmu dan kegitaan-kegiatan baik

29 Abdullah Nashihu I'lwan, Ahkamu az-Zakat a'la Dhawai al-Mazda>hib alArba'ah,(Kairo: Darul as-Salam,2000), hlm. 38.

${ }^{30}$ Mujamma' al-Malik Fahd lithobaa'h al-Mushaf as-Syarif. al-Qur'an Dan Terjemahnya, ( Madinah : 1418 H), hlm. 285.

${ }^{31}$ Abu Usamah Salim, Bahjatun Nazhirin Syarh Riya >dhish Sha>lihi >n (Kairo : Da>r Ibnul Jauzi, 1430 H), hlm. 255.

${ }^{32}$ Mujamma' al-Malik Fahd lithobaa'h., al-Qur'an ...hlm. 291.

${ }^{33}$ Ibid. hlm. 301. 
yang lainnya, dengan memiliki illat yang sama; bertujuan untuk menegakkan kalimah Allah dan membela agama Islam tanpa pamrih kecuali mengharap ridha Allah swt, maka kedudukannya sama dengan orang yang sedang berjihad dijalan Allah.

Mengkaji tentang qiyas sebagai metode istinbath hukum Islam tidak bisa terlepas dari salah satu bagian esensial dalam pembentukannya, yaitu tentang 'illat hukum. Oleh karena itu, pengetahuan tentang cara menemukan 'illat hukum sangat diperlukan. Sebab pembentukan qiyas ditentukan oleh ada dan tidak adanya 'illat hukum. ${ }^{34}$ Menganalogikan bahwa seorang pelajar yang sedang menuntut ilmu atau para guru, ustad, pendakwah, ulama yang sedang mengajarkan ilmu untuk kebaikan orang banyak, sehingga mereka meninggalkan pekerjaan untuk mencari nafkah dan lupa untuk membutuhi kebutuhan ekonomi pribadi dan keluarganya maka mereka ini berhak mendapatkan bagian harta zakat fisabilillah; karena i’llat nya memiliki kesamaan yang sama-sama bertujuan untuk kepentingan agama dalam menegakan dan memperjuangkan kalimah Allah. Dengan demikian, al-Qaradawi membolehkan pendistribusian harta zakat untuk keperluan ekonomi dan okomodasi para pendakwah atau para pelajar yang sedang menimba ilmu.

Kemudian penulis menemukan juga dari metode ijtihad yang digunakan alQaradawi dalam memecahkan permasalahna ini, memakai metode ma'nawiyah yang dapat diketahui dengan pendekatan maqasid al-Syariah melalui istislah yaitu metode penetapan hukum yang menggunakan pendekatan kemaslahatan. Kemaslahatan yang dimaksud adalah kemaslahatan yang akan mendatangkan kebaikan "جلب النفع" atau mencegah bahaya "دفع الضرر " bagi manusia itu sendiri.

Muatan kemaslahatan yang sejatinya mesti ada dalam pendekatan maqasid as" دفع الضرر" ataupun mencegah bahaya "جلب النفع "ariah; mendatangkan kebaikan dalam ijtihad al-Qaradawi adalah bisa membantu ekonomi para da'i ataupun pelajar, syiar Islam bisa terealisasi dengan baik dan sempurna berkat ajaran-ajaran Islam yang diterapkan di dalam kurikulum pendidikan Islam di sekolah-sekolah Islam. Sehingga tidak ada lagi pelajar atau mahasiswa yang menunggak bayaran sekolah atau putus sekolah karena minimnya biaya pendidikan yang ia miliki, atau para da'i mentelantarkan para jamaah pengajiannya karena sibuk pontang-panting mencari

\footnotetext{
${ }^{34}$ Fathurrahman Azhari," Qiyas Sebuah Metode Penggalian Hukum Islam”, Jurnal Syariah Jurnal Hukum dan Pemikiran, Vol.13, No.1, (Agustus 2013), hlm. 2.
} 
TAHKIM, Jurnal Peradaban dan Hukum Islam. Vol.2 No.l (Maret, 2019) | ISSN : 2597-7962

kerja atau penghasilan demi menutupi kebutuhan rumah tangganya, maka tepatlah sasaran pendistribusian zakat tersebut digunakan untuk kemaslahatan umat.

\section{SIMPULAN}

Dari analisis yang komprehensif mengenai ijtihad para ulama empat mazhab dan Yusuf al-Qaradawi tentang fisabilillah. Maka penulis menemukan bahwa posisi ijtihad al-Qaradawi dalam penelitian ini adalah kategori ijtihad kontemporer, mengintegrasikan antara ijtihad intiqai (selektif) dan ijtihad insyai (imajinatif) dalam memaknai fisabilillah. Ijtihad Yusuf al-Qaradawi dalam memaknai fisabilillah pada mustahiq zakat salah satunya telah menerapkan metode ijtihad lafdziyyah, berupa lafdz muqayyad yang dibatasi maknanya dengan arti orang yang berjihad, dan juga menerapkan metode takhshisu al-'Am dengan petunjuk dalil hadist sehingga maknanya menjadi pasti tidak mengandung beragam makna yang bersifat umum, menjadi khusus bermakna jihad.

Al-Qaradawi mengartikan fisabilillah dengan jihad, sebagaimana yang diartikan para ulama tafsir umumnya. Akan tetapi jihad yang dimaksudnya adalah

jihad yang dilihat dari tujuan arti jihad yang sebenarnya. Dari elaborasi makna jihad inilah kemudian al-Qaradawi menggunakan dalil hadist untuk menjelaskan makna jihad bukan hanya sekedar berjuang mengangkat senjata, berperang secara fisik melawan musuh Allah di medan perang namun jihad beragam cara dan objeknya. Selain itu juga al-Qaradawi telah menerapakan metode ijtihad ma'nawiyah, melalui qiyas dan istislah. 
TAHKIM, Jurnal Peradaban dan Hukum Islam. Vol.2 No.l (Maret, 2019) | ISSN : 2597-7962

\section{DAFTAR PUSTAKA}

Abdul Hamid, Muhidin. (1990). Sabilulfalah fi Syarhi Nurulidhoh lilsyarnabulani, Damsuq: Darul al-Biruti.

Ali, al-Sayis Muhammad. (1970). Nasy'ah al-Fiqh al-Ijtihadi wa Athwaruh, Cairo : Majma' al-Buhuts al-Islamiyyah.

Abu Zahra, Muhamad. (1995). Zahratu at-Tafasir, Kairo : Darul al-Fikri al-Arabi.

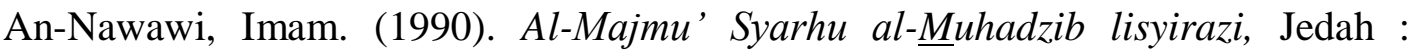
Maktabah al-Irsyad.

Al-Malik, Mujamma' Fahd lithobaa'h al-Mushaf as-Syarif. (1418 H). al-Qur'an Dan Terjemahnya. Madinah : Mujamma' al-Malik Fahd lithoba $>$ a'h alMushaf as-Syarif.

Ali, Atabik Ahmad Zuhdi Muhdlor. (1999). Kamus Kontemporer Arab-Indonesia, Yogyakarta : Multi Karya Grafika.

Al-Qardawi, Yusuf . (1994). Fiqhul Zakah, Cairo: Maktabah Wahbah. . (2001). Min Ajl Shahwah Rasyīdah; Tujaddid al-Dīn wa Tanhadh bi al-Dunyā. Cairo: Dar al-Syuruq. . (1987). Ijtihad Dalam Syariat Islam Beberapa Pandangan Analitis tentang Ijtihad Kontemporer, terj : Achmad Syathori, Jakarta: PT Bulan Bintang.

Aminah, Siti. (2015). Pengaruh Pemikiran Fiqh Yusuf al-Qardhawi Di Indonesia, Jurnal Ummul Qura, Vol V, No. 1, Maret.

Azhari, Fathurrahman. (2013). Qiyas Sebuah Metode Penggalian Hukum Islam, Jurnal Syariah Jurnal Hukum dan Pemikiran, Vol.13, No.1, Agustus.

Djazuli, A. (2005). Ilmu Fiqh, Perkembangan dan Penerapan Hukum Islam,Jakarta: Kencana.

Hosen, Ibrahim. (2003). Fiqh Perbandingan, Masalah Pernikahan, Jakarta: Pustaka Firdaus.

Ibnu, Ahmad Muhamad Ibnu Qudamah al-Hanbali. (1997). Al-Kafi, Kairo : Hajar. Islam, Universitas Indonesia. (1995). Al-Qur'an dan Tafsirnya, Yogyakarta : PT Dana Bhakti Wakaf.

Muhammad, Abu Abdulwahab al-Bagdadi. (2003). At-Talqin fi al-Fiqhi al-Maliki, Ar-Riyad:Nazar Mustofa. 
TAHKIM, Jurnal Peradaban dan Hukum Islam. Vol.2 No.l (Maret, 2019) | ISSN : 2597-7962

Muhammad, Abu Abdullah bin Ahmad al-Anshari al-Qurtubi.(1962). al-Jami li Ahkam al-Quran, Kairo : Dar al- Kitab al-Arabi.

Muhamad, Teungku Hasbi Ash Shiddiqy. (1995).Tafsir Al-Qur'anul Majid An-Nur, Semarang : PT Pustaka Rizki Putra Semarang.

Nashihu I'lwan, Abdullah. (2000). Ahkamu az-Zakat a'la Dhawai al-Mazdahib alArba'ah,Kairo: Darul as-Salam.

Romli. (1999). Muqaranah Mazahib Fil Ushul, Jakarta: Radar Jaya Pratama.

Satori, Djam`an, Aan Komariah. (2009). Metodologi Penelitian Kualitatif, Bandung : Alfabeta.

Sabiq, Sayyid. (2006). Fiq $\underline{h} u$ as-Sunnah, Kairo: al-Fathu lili'lami al-A'rabi.

Safi, Hasan Abu Talib. (1990). Tatbiq al-Syari'ah al-Islamiyah Fi al-Bilad alArabiyah, Kairo : Dar al-Nahdah al-Arabiyah.

Surin ,Bachtiar. (1991). Adz-Dzikraa Terjemah \& Tafsir Al-Qur'an, Bandung, Angkasa Bandung. 